Post-Print Version of Conway and Hackworth, 2007. Urban pattern and land cover variation in the greater Toronto area. The Canadian Geographer / Le G'eographe Canadien 51(1), 43-57

Urban Pattern and Land Cover Variation in the Greater Toronto Area

\author{
Tenley Conway* \\ Department of Geography \\ University of Toronto \\ 100 St. George St. \\ Toronto, ON \\ M5S 3G3 \\ T: $905-828-3928$ \\ F: 905-828-5273 \\ tenley.conway@utoronto.ca \\ Jason Hackworth \\ Department of Geography \\ University of Toronto \\ 100 St. George St. \\ Toronto, ON \\ M5S 3G3 \\ T: 416-946-8764 \\ F: 416-946-3886 \\ jason.hackworth@utoronto.ca \\ * Corresponding Author
}


Post-Print Version of Conway and Hackworth, 2007. Urban pattern and land cover variation in the greater Toronto area. The Canadian Geographer/Le G'eographe Canadien 51(1),43-57

\section{Urban Pattern and Land Cover Variation in the Greater Toronto Area}

\section{ABSTRACT}

Recent epistemological shifts in environmental geography have created a space to consider the interactions between ecological and urban systems more seriously. But while openness to thinking about urban ecosystems has increased in recent years, there are still fundamental gaps in our knowledge. For example, recent research has examined the impact of urban-rural gradients on ecological conditions, but major voids exist regarding the relationship between urban development patterns and land cover heterogeneity, particularly for new forms of urbanization. This paper attempts to address some of these gaps by examining the relationship between urban pattern and land cover in the Greater Toronto Area. In particular, measures of urban pattern that reflect aspects of development density, grain, and function, as well as socioeconomic characteristics, are systematically analyzed in relation to land cover heterogeneity. The regression analysis shows that multiple components of urban development pattern and socioeconomic conditions are correlated with vegetated land covers, while urban density variables are not related. These results indicate more detailed representations of urban pattern should be incorporated into future human-environmental interaction studies in cities.

Les variations epistemologiques récentes dans la géographie environnementale ont créé un espace pour considérer les interactions entre les systèmes écologiques et urbains plus sérieusement. Par contre, même s’il existe une ouverture pour considérer les ecosystèmes urbains, il reste des lacunes fondamentales dans notre connaissance. Par exemple, la recherche récente a examiné l'impact des gradients urbains et ruraux sur des conditions écologiques, mais il 
Post-Print Version of Conway and Hackworth, 2007. Urban pattern and land cover variation 2 in the greater Toronto area. The Canadian Geographer/Le G'eographe Canadien 51(1),43-57

reste des omissions importantes concernant le rapport entre les modèles de développement urbain et l'hétérogénéité de la couverture de terre, en particulier en guise de nouvelles formes d'urbanisation. Cet article tente d'adresser certaines de ces lacunes en examinant le rapport entre le modèle urbain et la couverture végétale dans la région du Grand Toronto (RGT). En particulier, les measures du modèle urbain qui reflète la densité, le grain et la fonction, ainsi que les caractéristiques socio-économiques sont systématiquement analysées par rapport à l'hétérogénéité de la couverture de terre. L’analyse de régression démontre que plusieurs componsantes du développement urbain ainsi que les conditions socio-éeconomiques sont corrélés avec le type de couverture végétale alors que les variables traditionnelles de densité urbaine ne sont pas connexes. Ces résultats indiquent que des représentations plus détaillées de modèle urbain devraient être incorporées à de futures études qui se concernent avec les interactions humain-environmentales citadines. 
Post-Print Version of Conway and Hackworth, 2007. Urban pattern and land cover variation

\section{INTRODUCTION}

Environmental geography has historically neglected the study of cities in favour of locales where the human-environmental interface is most exposed- in particular, spaces where resources are extracted or harvested from the earth (Robbins et al. 2001; Slocombe 2000). This anti-urban bias historically influenced the field of ecology as well, albeit for slightly different reasons; ecologists have been sceptical about the usefulness of studying ecological systems that are so polluted and altered by human intervention (Luck and Wu 2002). Cities have thus been framed as supremely un-natural (Pickett et al. 1997), and remained the purview of 'purely' social scientists- urban geographers, planners, and sociologists in particular.

In recent years, the urban-nature dualism has begun to break down as both environmental geographers and ecologists become interested in the unique contexts that cities pose for environmental research. Part of this shift is epistemological, influenced by years of geographers challenging the notion that nature is everything non-human (Smith and O’Keefe 1980). Part of the shift is related to policy concerns as the world's population continues to urbanize at rapid rates. Regardless of the specific reasons, it is clear that environmental geographers and ecologists are concerning themselves with cities as never before (Botkin and Beveridge 1997; McIntyre et al. 2000; Robbins et al. 2001; Zipperer et al. 2000).

But while openness to thinking about urban ecosystems has increased in recent years, there are still fundamental gaps in our knowledge about human-environmental interactions in urban settings. Those studies that have occurred tend to examine one ecological component (i.e. soil, vegetation, air quality) in a city or conduct studies analyzing biophysical flows across a city, while paying relatively little attention to human components (Alberti 2005; McIntyre et al. 2000; Pickett et al. 2001). The relationship between urban form and land cover, for example, contains 
Post-Print Version of Conway and Hackworth, 2007. Urban pattern and land cover variation in the greater Toronto area. The Canadian Geographer/Le G'eographe Canadien 51(1),43-57 major voids, particularly for new forms of urbanization (Alberti 2005; Miller and Small 2003). These gaps are unfortunate not only because of high rates of global urbanization, but also because the expansion of urban land uses has tremendous localized impacts on the populations of those cities. A better understanding of the interface between urban pattern and land cover could specifically assist the development of policy that ameliorates attendant problems, and generally assist the goal of building an "ecological city” (White 2002).

This paper attempts to address some of these gaps by examining the relationship between land cover and urban pattern in the Greater Toronto Area. In particular, measures of development pattern that reflect specific aspects of density, grain, and function, as well as socioeconomic characteristics are analyzed to systematically explore the effects of urban pattern on land cover heterogeneity. A simple vegetation index (NDVI- the Normalized Difference Vegetation Index) extracted from a 1999 satellite image is used to represent land cover because the focus of the paper is on disentangling the influential components of urban pattern ${ }^{1}$. Three questions are addressed through this analysis: (1) can variations in NDVI be explained by distance to city centre alone? (2) what is the relationship between NDVI and different urban land uses? and (3) what other aspects of urban pattern are correlated with NDVI? The paper concludes with a discussion of future research pathways and the environmental planning implications of the analysis.

\footnotetext{
${ }^{1}$ The use of NDVI to represent land cover is not meant to imply that human-environmental interactions can be fully represented by this simple measure. Rather, land cover is one important component of those interactions.
} 
Post-Print Version of Conway and Hackworth, 2007. Urban pattern and land cover variation

in the greater Toronto area. The Canadian Geographer/Le G'eographe Canadien 51(1),43-57

\section{URBAN PATTERN AND ECOLOGICAL CONDITIONS}

In response to a growing interest in the ecology of urban areas, McDonnell and Pickett (1990) suggest an urban-rural gradient approach to studying urban ecological conditions. Built factors are thought to be equal to or supersede biophysical factors governing ecological conditions in urban landscapes, so a gradient of urban intensity provides a way to study the dominant influence on urban ecological conditions. In particular, urban-rural gradients represent a unique situation where "experimental” conditions with varying levels of urbanization exist that researchers are otherwise unable to create (McDonnell and Pickett 1990). Most urban-rural gradient studies delineate one or more linear transects across a metropolitan area, using a moving window approach when relying on remotely sensed data (Luck and Wu 2002) or discrete plots along the gradient for field data collection (McDonnell et al. 1997). Such an approach has now been used to examine land use (Luck and Wu 2002; Zhang et al. 2004), vegetation and other land covers (Medley et al. 1995), species diversity (Blair 1996; Sukopp 1998), microclimate variation (Miller and Small 2003), soil processes and pollution (Pouyant and McDonnell 1991; Pouyant et al. 1995), and water quality (Wear et al. 1998).

While gradient studies have provided a foundation for understanding urban ecological conditions, the approach implicitly assumes that cities are monocentric, with outward gradients of decreasing density. However, many metropolitan areas are polycentric entities sprawling in fractal or spider-like configurations (Batty and Xie 1996; De Keersmaecker et al. 2003; Longley and Mesev 2000; White and Engelen 1993), indicating that the gradient approach many not capture all of the relevant built dimensions. Alternatively, Alberti (1999) identifies a total of four urban development pattern components that likely interact with ecological factors at the metropolitan scale: density, grain, connectivity, and form. Density refers to the population, 
Post-Print Version of Conway and Hackworth, 2007. Urban pattern and land cover variation in the greater Toronto area. The Canadian Geographer/Le G'eographe Canadien 51(1),43-57 employment, or building density variation that is often assumed to occur along urban-rural gradients. Grain represents the diversity of functional uses, while connectivity refers to the circulation of people and goods across a landscape. Alberti defines form as the level of centralized or decentralized development in a metropolitan area ${ }^{2}$.

To date, only a few studies have evaluated the influence of urban pattern on ecological conditions beyond simple density or urban-rural gradient measures. Stone (2004) looked at the relationship between impervious land cover and street pattern in addition to lot density and several site level variables. Wilson et al. (2003) found that variations in urban vegetation cover were statistically different between zoning classes in the Indianapolis metropolitan area, but they did not examine the configuration of those classes nor reasons for between class variations. Hope et al. (2003) investigated the impact of distance from city centre on plant diversity, but determined that current and past land use, housing age, and household income were better correlated with diversity in their Phoenix metropolitan study area.

There is also growing evidence that socioeconomic factors play a key role in urban ecosystem interactions. In the Chicago area, Iverson and Cook (2000) found household income highly related to land cover composition. A Phoenix-based study focusing on residential neighbourhood parks indicated that even urban parkland's plant diversity is a result of a "luxury effect” reflecting neighbourhood socioeconomic conditions (Martin et al. 2004). These results lead Kinzig et al. (2005) to suggest that inclusion of socioeconomic variables into traditional urban-rural gradient studies can improve explanations of intra-urban biodiversity patterns.

\footnotetext{
${ }^{2}$ Alberti (1999) has adopted a narrower definition of form than is often used. An example of a specific measure that falls under her definition is: within a metropolitan areas are jobs highly centralized in one location, primarily located in several centers (polycentric form), or spread throughout the metropolitan area (decentralized)?
} 
Post-Print Version of Conway and Hackworth, 2007. Urban pattern and land cover variation in the greater Toronto area. The Canadian Geographer/Le G'eographe Canadien 51(1),43-57

In a major North American metropolitan area such as Toronto, we would expect that a simple distance to city centre measure would not be a good predictor of land cover or broader ecological heterogeneity given the complexity of urban pattern present and previous findings from other regions. Instead, more specific aspects of urban development pattern, coupled with local socioeconomic characteristics, are likely the primary drivers of ecological variation in such settings. The following section describes the methods used to systematically detangle development pattern and socioeconomic factors that are related to land cover conditions in the Toronto area.

\section{METHODS}

\section{Study Area}

The study area includes the five regional municipalities that make up the Greater Toronto Area (GTA) in southern Ontario (Figure 1). The remnant shoreline from glacial Lake Iroquois divides the 5,902 $\mathrm{km}^{2}$ region into two main physiographic areas. South of the glacial lake’s shoreline is a sandy plain stretching 2 to $10 \mathrm{~km}$ to Lake Ontario. North of the remnant shoreline is a gently sloping clay and till plain. A series of glacial moraines exist along the northern edge of the study area, while the Niagara Escarpment crosses Halton Region in the West. Several river systems transect the region, primarily draining into Lake Ontario. Vegetation is composed of the Great Lakes-St. Laurence mixed forest type and Carolinian species like the tulip tree (Liriodendron tulipifera), sycamore (Plantanus occidentalis), and chestnut oak (Quercus prinus) (Wickware and Rubec 1989).

Most of the region was cleared for agriculture in the $19^{\text {th }}$ century. The original city settlement and several other small towns were located on the sandy plain between the Lake 
Post-Print Version of Conway and Hackworth, 2007. Urban pattern and land cover variation in the greater Toronto area. The Canadian Geographer/Le G'eographe Canadien 51(1),43-57 Iroquois’ shoreline and Lake Ontario. Today a substantial portion of the GTA’s urban development is still located on this plain. By 1940, the majority of the clay and till plain to the North was used as cropland, with only about six percent of the land in woodlots (Chapman and Putnam 1984). However, the second half of the $20^{\text {th }}$ century saw urban development expanding outwards from Toronto, converting agricultural lands to the North and engulfing previously separate small towns.

By 2001, the study area had a population just over 5 million people. With an annual growth rate of 1.9 percent, the GTA is one of the fastest growing large metropolitan regions in North America. In the study area, approximately 13 percent of the land is used for urban residential purposes, 8 percent for commercial and industrial activities, and 3 percent is protected parkland. The remaining 77 percent is agricultural, rural residential development, forests, and wetlands. Today, the region includes several commercial centres, often remnants of previously separate urban settlements; significant industrial and commercial strip development along highways and major roads; high density older residential neighbourhoods; and extensive single family suburban development.

Though no two urban landscapes are perfectly identical, the GTA possesses a variety of structural characteristics that make it suitable for a study of this sort. In particular, it has elements of polycentric growth but still retains an economically significant downtown core. It also displays an interesting combination of dense inner city urban structure, with diffuse autocentred suburban growth. At least one geographer has even suggested that these features (and others) place Toronto on the vanguard of urbanization for North America (Lemon, 1996). Though we do not wish to enter this debate here, we do argue that Toronto possesses a mixture of characteristics that make it useful for a study of urban form in North America. 
Post-Print Version of Conway and Hackworth, 2007. Urban pattern and land cover variation

\section{Land Cover Data}

The Normalized Difference Vegetation Index (NDVI) was chosen to represent land cover because it is strongly correlated with urban land cover type (Fung and Siu 2000), and provides additional information about the amount of green biomass present (Tucker 1979). The index is also correlated with broader ecosystem processes, like the level of photosynthetic activity (Reed et al. 1994). The index is a ratio of near infrared (NIR) and visible red (R) reflective values defined by the following formula:

$$
\mathrm{NDVI}=\frac{\mathrm{NIR}-\mathrm{R}}{\mathrm{NIR}+\mathrm{R}}
$$

Highly vegetated areas have an NDVI value closer to 1, while locations dominated by water, impervious surfaces, or bare soil have values closer to -1 .

In this study, NDVI was calculated from Landsat 7 ETM+ satellite imagery. The imagery has a cell size of $30 \mathrm{~m}$, an appropriate resolution for metropolitan-wide studies of NDVI variation (Wilson et al. 2003). Two images were needed to cover the study area. Images collected two weeks apart were used to minimize cloud coverage: Path 18 Row 29 on September 3, 1999 and Path 18 Row 30 on September 19, 1999. The images were corrected for radiometric distortions and georeferenced to the Universal Transverse Mercator, Zone 17 by the US Geological Survey’s Earth Resource Observation Systems Data Centre. The two images were mosaiced and digital number values adjusted to minimize between image differences using IDRISI software.

\section{Urban Pattern and Socioeconomic Variables}

Ten variables were included in the analysis to reflect neighbourhood or site-level components of urban development pattern (Table 1). While metropolitan-wide measures, such 
Post-Print Version of Conway and Hackworth, 2007. Urban pattern and land cover variation 10 in the greater Toronto area. The Canadian Geographer/Le G'eographe Canadien 51(1),43-57 as degree of centralization, were not considered, the characterization of urban development at finer scales enables the exploration of intra-metropolitan variations. The first variable is distance from city centre. The centre was defined as the core financial district identified by the City of Toronto. Three additional variables representing urban density were also included: parcel size, population density, and road density. Population density represents the number of people per square kilometre in each census dissemination area. Dissemination areas contain a population of 400 to 700 persons, and are the smallest geographical unit for which all census data is released. Road density was measured within a $1.0 \mathrm{~km}$ neighbourhood following Geoghegan et al. (1997). Six other variables were included to represent additional aspects of urban development pattern. Age of housing was determined based on the dominat age of construction for a given dissemination area. Two variables associated with neighbourhood diversity, similar to Alberti's (1999) grain, were identified. The number of land use classes within a $1.0 \mathrm{~km}$ neighbourhood is a broad measure of the diversity of neighbouring functions, with a higher number of land use classes suggesting a mixed use development pattern over single use configurations. Land use was based on DMTI’s 1999 data derived from the National Topographic Database and other datasets. It includes six classes: government and institutional, industrial, commercial, residential, recreational parks, and open area. Open area includes agriculture, as well as rural residential, forest, wetlands, and protected ravines. The percent of owner-occupied dwelling units within each dissemination area was included as a measure of diversity in residential uses. Three variables reflect the degree of structural connectivity, which influence the circulation of people and goods: (1) percent of neighbourhood used for industrial/commercial purposes; (2) percent of neighbourhood greenspace (open area and parks); and (3) percent of neighbourhood parkland. Like road density, neighbourhoods were defined by the $1.0 \mathrm{~km}$ surrounding area. 
Post-Print Version of Conway and Hackworth, 2007. Urban pattern and land cover variation 11 in the greater Toronto area. The Canadian Geographer/Le G'eographe Canadien 51(1),43-57

To capture socioeconomic and site conditions, seven additional variables were included in the analysis. Median household income and average value of dwelling unit were included to represent household economic conditions. The average number of rooms per housing unit is included as a proxy for building size. The above variables are all based on the 2001 Census data for a given dissemination area, so more localized variations are not captured ${ }^{3}$. However, Hope et al. (2003) concluded that US census block data, which are similar to dissemination area data, is appropriate for this type of analysis.

At the site level, land use and several variables reflecting view were identified. View variables were included because previous research in urban landscapes has suggested that property owners prefer a view of certain features over others (Kaplan 2001). Given the lack of topographic variation across the region, viewsheds were defined using a $0.1 \mathrm{~km}$ neighbourhood around each sample point, following Geoghegan et al. (1997). Similar to neighbourhood uses, views of parkland and greenspace (parkland and open land) were examined.

If the study area represented a monocentric city with an outward density gradient and NDVI is primarily determined by urban density, then we would expect NDVI to be highly correlated with distance to city centre. A stronger positive correlation between NDVI and the density variables would be seen if urban density is related to NDVI, but density does not decrease as one moves outward from the city centre. We expect that the three density variables

\footnotetext{
${ }^{3}$ Because the census data is based on a spatial unit of analysis much larger than 30 meters, the census variables should be interpreted as representing average neighbourhood conditions rather than cell specific characteristics. In addition, the census data represents conditions two years after the NDVI data was collected. While ideally the data should represent the same time, the ranged of dates captured in this study is similar to previous studies comparing satellite imagery to other data sources (Heymen and Lindsey 2003; Iverson and Cook 2000; Kinzig et al. 2005).
} 
Post-Print Version of Conway and Hackworth, 2007. Urban pattern and land cover variation 12 in the greater Toronto area. The Canadian Geographer/Le G'eographe Canadien 51(1),43-57

will be more strongly correlated with NDVI than distance to city centre because greater urban density is typically associated with lower levels of vegetated land covers, but the GTA does not strictly follow an outward density gradient. We expect older construction to be associated with higher NDVI values because those areas have experienced a longer stable period since the last major disturbance (i.e. construction), allowing more biomass to accumulate (Hough 1995). Alternatively, greater functional diversity is expected to be associated with lower NDVI because such areas are likely to be associated with high land cover heterogeneity. We assume a "luxury effect” exists in the study area due to findings from previous studies (Hope et al. 2003; Iverson and Cook 2000; Martin et al. 2004). We also expect site-level land use to be related to NDVI, but as many vegetated land covers can exist within one type of land use, land use alone is not likely to be a strong predictor of NDVI. Finally, property-owners with a view of greenspace likely make different landscaping choices than those with a view of industrial or commercial land uses, so we assume that view will be highly correlated with NDVI.

\section{Analysis}

Given the size of the study area, a sampling approach was employed in the analysis. Transects were used to examine the different types of urban-rural gradients that exist within the GTA. Each transect is $2 \mathrm{~km}$ wide, originating from the city centre and extending to the edge of the study area (Figure 1). The initial transect was created running a line parallel to the major North-South road network (Transect A). Two additional transects were delineated at 45 degree angles from the first (Transects B and C). A final transect follows Lake Ontario's shoreline west of the city (Transect D). While other studies have used perpendicular transects through the 
Post-Print Version of Conway and Hackworth, 2007. Urban pattern and land cover variation 13 in the greater Toronto area. The Canadian Geographer/Le G'eographe Canadien 51(1),43-57

centre of the city (Luck and Wu 2002), the relationship between the metropolitan area and Lake Ontario did not make this approach feasible.

Transect A and D both follow development corridors, with Transect A $58 \mathrm{~km}$ long and Transect D $82 \mathrm{~km}$ (Figure 2). Transects B (76 km) and C (58 km) cross the western and eastern suburbs, respectively. Transect A is 43 percent residential and 37 percent open land, while transects B and C are approximately 60 percent open land, and 13 and 18 percent residential, respectively. Transect D has approximately the same level of residential uses (47 percent) as Transect A, but it contains only 14 percent open land. Non-residential urban uses (commercial, industrial, government, and institutional) comprise 12 percent (Transects A and B) to 27 percent (Transect D) of the land. A $1 \mathrm{~km}$ moving window analysis showed that land uses are most diverse closest to the city centre. There is a very gradual transition from residential to open land uses in Transect A and a sharp divide for Transects B and C. Residential uses are almost continually dominant along the entire length of Transect D.

For the analysis, roads and water bodies in the transects were excluded to ensure that NDVI values reflect conditions on land and were not skewed by cells centred on a roadway; cell exclusions enable the examination of changing conditions on non-transportation land along the transects. Of the remaining cells, 10 percent from each transect were selected (representing 6,342 to 15,204 cells), using a spatially-stratified sampling approach to minimize autocorrelation effects that are present in the NDVI data and many of the other variables. The sample size was determined based on a lag distance that exhibited only weak autocorrelation for NDVI. All of the development pattern and socioeconomic variables were converted to a $30 \mathrm{~m}$ grid to match the NDVI data. 
Post-Print Version of Conway and Hackworth, 2007. Urban pattern and land cover variation 14 in the greater Toronto area. The Canadian Geographer/Le G'eographe Canadien 51(1),43-57

To address our first question regarding the relationship between NDVI and distance to city centre, NDVI was mapped for the entire study area and correlations calculated for each transect. The second question, the influence of land use on NDVI, was examined by comparing the mean and range of NDVI for each of the six land use classes. An ANOVA was calculated to determine if mean NDVI values differed significantly between land use classes. A post-hoc test using Tamhane’s T2 was conducted to identify significant differences between specific pairs of land use classes. Tamhane’s T2 was chosen because it minimizes Type I error and is appropriate to use when variation or sample size differs between populations.

To address the third question, a regression analysis between NDVI and the development pattern and socioeconomic variables was conducted. The variables listed in Table 1 were used in this analysis. The analysis was performed separately on the four transects to determine if factors had varying relationships with NDVI across the metropolitan area. We expect to see such differences given that urban development in the GTA does not fit a simple monocentric pattern, but has highly developed linear corridors (Transects A and D) and sections that have simple outward density gradients (Transects B and C). Correlations using Pearson’s moment correlation coefficient were calculated between NDVI and the independent variables. A stepwise linear regression analysis was then conducted to determine the level of variance explained by the urban development pattern and socioeconomic variables.

\section{RESULTS}

Transects A, B, and C have nearly identical ranges for NDVI (-0.28 to approximately 0.50), while transect $\mathrm{D}$ has a slightly smaller range (-0.30 to 0.40). In general, lowest values, indicating less biomass, are found closest to the centre of city, with several protected ravines and 
Post-Print Version of Conway and Hackworth, 2007. Urban pattern and land cover variation 15 in the greater Toronto area. The Canadian Geographer/Le G'eographe Canadien 51(1),43-57 inner city parks highlighted (Figure 3). These results are not surprising, indicating that NDVI does differ between the centre city and rural hinterlands as we would expect. However, NDVI along the southern edge of the region, in Transect $\mathrm{D}$, does not have highly contrasting values further from the city centre, reflecting the nearly continuous high density urban development along the lakeshore from the city centre across to western Halton. High levels of variation in NDVI at similar distances also suggest that distance to city centre alone cannot be used to explain metropolitan-wide variations in NDVI.

Given that land uses along each transect are distributed unevenly, can the variation in NDVI be explained by land use? The ANOVA results indicate that significant differences exist ( $<<0.001)$. Of the 144 pairs of land use classes (36 pairs per transect), 141 have significantly different means $(\mathrm{p}<0.05)$. The pairs that are not significantly different are governmentresidential in Transect A and open land-parks and residential-industrial in Transect C. However, the range in NDVI values for most land use classes is close to the entire range for a given transect (Figure 4). These results suggest that land use alone cannot be used to differentiate NDVI values.

An examination of the correlation results indicate that other factors, beyond distance to city centre and land use, are also related to NDVI levels (Table 2). For Transect A, the variables most strongly correlated with NDVI are neighbourhood industrial/commercial density, average number of rooms, percent road view, neighbourhood road density, and percent greenspace view. Distance to city centre and population density are only weakly correlated with NDVI indicating that a simple distance or density-land cover relationship does not occur along this transect. Interestingly, population, average number of rooms, and percent neighbourhood industrial/ commercial are only weakly correlated with distance to centre. These results suggest that the 
Post-Print Version of Conway and Hackworth, 2007. Urban pattern and land cover variation 16 in the greater Toronto area. The Canadian Geographer/Le G'eographe Canadien 51(1),43-57

intensity of urban activities does not decrease as one moves away from the city centre, so that in this transect distance to city centre is not capturing a simple gradient of urban to rural uses.

Similar but slightly stronger correlations exist for Transect B: percent greenspace view, neighbourhood greenspace density, average number of rooms, neighbourhood road density, and distance to city centre are most strongly correlated. Unlike transect A, neighbourhood land use diversity has a moderate negative correlation and two socioeconomic measures (average dwelling unit value and median household income) have weak but positive correlations with NDVI.

Transect $\mathrm{C}$ exhibits the strongest distance gradient as many of the independent variables and NDVI are correlated with distance to city centre: road and population density are negatively correlated with distance to centre city and NDVI, while median household income and average number of rooms are positively correlated. NDVI is also most highly correlated with percent greenspace view, neighbourhood greenspace density, neighbourhood road density, and percent road view. Like transect B, neighbourhood land use diversity has a moderate negative correlation.

NDVI is most positively correlated with the number of rooms, percent of owner-occupied dwellings, distance to city centre, average value of dwelling units, and negatively correlated with percent neighbourhood commercial in Transect D. The "luxury effect" is most obvious in Transect D, with all four socioeconomic variables moderately correlated with NDVI. This is a notable difference from Transect A, the other transect following a development corridor, where only the number of rooms shows a moderate correlation.

The step-wise regression analysis indicates that only 37 to 52 percent of the total variance in NDVI was explained by the development pattern and socioeconomic variables (Table 3). In 
Post-Print Version of Conway and Hackworth, 2007. Urban pattern and land cover variation 17 in the greater Toronto area. The Canadian Geographer/Le G'eographe Canadien 51(1),43-57

Transects B and C, distance to city centre explained the most variance. While distance to city centre was also included for Transects $\mathrm{A}$ and $\mathrm{D}$, none of the other density variables were incorporated for any of the transects. In addition to distance to city centre, socioeconomic and view variables were most heavily loaded, but the seven to nine variables retained for each transect suggest that no one factor can be used to explain NDVI heterogeneity in the GTA. All $\mathrm{r}^{2}$ values should be interpreted with caution, however, as results are likely influenced by the collinearity that exists among many of the independent variables.

\section{DISCUSSION}

The results of this study support Alberti’s (1999) assertion that urban ecological conditions are more than a simple function of distance from centre. We found that the density, function, and connectivity of urban development ${ }^{4}$, as well as socioeconomic factors are all related to metropolitan-wide variation in NDVI. Counter to our initial assumptions, distance to city centre was consistently correlated with NDVI, and more highly correlated than any of the urban density variables, supporting the idea that more complex aspects of urban development pattern and socioeconomic factors related to land cover variations may be oriented along such a gradient. However, only in Transects B and C did distance to city centre have the strongest loading, with variables reflecting connectivity, view, and socioeconomic factors more strongly correlated in the other transects. These results highlight the limitations of assuming that ecological gradients always follow simple urban-rural distance gradients. While some sections of a metropolitan area may exhibit clear distance gradients (Transect C), other parts of the same metropolitan area will potentially follow neither an outward population nor ecological gradient.

\footnotetext{
${ }^{4}$ We did not examine any variables that fall under Alberti’s (1999) definition of form.
} 
Post-Print Version of Conway and Hackworth, 2007. Urban pattern and land cover variation 18 in the greater Toronto area. The Canadian Geographer/Le G'eographe Canadien 51(1),43-57

The normally-strong predictor of ecological conditions, population density, shows relatively little or no relationship with NDVI in the GTA. This result may be a reflection of the generally-uniform level of density in residential areas and sharp difference between residential and rural densities that exists in the GTA as compared to many other North American cities. Correlations with either parcel size or age would support physical space and disturbance regime explanations made by Hough (1995), but these factors do not seem to be influencing NDVI in the study area. The relatively high level of canopy cover in the GTA and strong urban tree bylaws in many municipalities may negate the typical influence of parcel size and house age. However, several studies showing such a relationship were based in Phoenix, where differences between undeveloped, newly developed and older neighbourhoods may be more pronounced, given the desert environment and common practice of planting non-desert exotic species (Hope et al. 2003).

These results support the role of a "luxury effect” for Transects B, C, and D. More rooms, higher household income, and greater house values are all associated with higher NDVI values. The relatively high correlation for average number of rooms, a proxy for house size, and very low correlation between parcel lot size and NDVI appear to be somewhat conflicting if we assume larger houses are generally on larger lots. But in all transects, the relationship between the average number of rooms and parcel size is extremely weak, indicating that the high positive correlation for rooms is not capturing parcel size effects. Rather, number of rooms is related to wealth as it is highly correlated with median household income and average house value. Interestingly, the average number of rooms is also more strongly correlated with NDVI than median household income or average house value. Further research should more closely 
Post-Print Version of Conway and Hackworth, 2007. Urban pattern and land cover variation 19 in the greater Toronto area. The Canadian Geographer/Le G'eographe Canadien 51(1),43-57 examine the relationship between these three variables to address whether there is a "monster house” effect, and if that is separate from the luxury effect that seems to exist.

At first glance the results of the analysis appear to contradict Stone's (2004) concerns that higher density requirements often reduce the amount of urban vegetation cover. However, high density could still be associated with a lower level of vegetation cover as NDVI primarily captures canopy cover, which has positive effects on factors like urban heat flux (Wilson et al. 2003), but does not specifically represent conditions under the canopy. Many areas that have high canopy cover in the GTA also likely have high levels of impervious surface and nearly impervious lawn grass underneath, which may mean significant hydrological and species-level impacts still exist.

The surprising lack of a relationship between housing age, parcel size, population density, and NDVI suggests that higher densities and/or newer development do not necessarily mean a localized reduction in vegetation. This is a positive result for regions like the GTA which are working to increase density in existing urban areas as a way to limit encroachment into surrounding greenfields. However, road density is clearly negatively associated with NDVI, so approaches to reduce the length of roads, such as the Canadian Mortgage and Housing Corporation's reduced road density Fused Grid Model (CMHC 2002) could lead to increases in vegetation. At the same time, the negative relationship between NDVI and greater neighbourhood functional diversity highlights the fact that attention should be paid to vegetated land cover in mixed use development.

For all transects, socioeconomic variables were able to explain a relatively high level of NDVI variance. The tendency for wealthier neighbourhoods to have greater biomass is well documented (Hope et al. 2003; Iverson and Cook 2000), with Lo and Faber (1997) concluding 
Post-Print Version of Conway and Hackworth, 2007. Urban pattern and land cover variation 20 in the greater Toronto area. The Canadian Geographer/Le G'eographe Canadien 51(1),43-57

that NDVI can be used as a surrogate for quality of life. The NDVI-socioeconomic results also indicate that many of the positive benefits of urban vegetation- increased sense of well being, filtration of air pollution, cooling effects, and access to greenspace (Kaplan 2001; Lo and Faber 1997; Sukopp and Hejný 1990)- are not found as frequently in poorer sections of the region. As a result, planning could focus on increasing green biomass in these areas.

An assumption that is either explicit or implicit in much of the urban ecology literature is that people need to see ecological features in their everyday lives in order to be interested in ecological conservation at home and elsewhere (Norton 2000; O’Connell 1996). At a very local level, this study supports the idea that people who encounter higher levels of biomass in their neighbourhoods may be more likely to have high biomass on their own property. In particular, the moderate correlations for neighbourhood greenspace and percent greenspace view for Transects A, B, and C suggest that incorporation of greenspace into new developments may lead to increases in vegetation on neighbouring property, irrespective of socioeconomic status. However, the interactions between protected greenspace and neighbourhood characteristics needs to be examined in more detail, as Martin et al. (2004) found that their was still a "luxury effect” on plant diversity in neighbourhood parks.

Many North American metropolitan areas do not reflect a monocentric pattern, and as a result, the reliance on simple urban-rural gradients or urban density measures in urban ecological studies does not capture many important aspects of urban pattern. Transect C indicates a simple urban-rural density gradient that is related to land cover can exist within complex metropolitan areas. However, Transects A and D explicitly follow development corridors where land cover variation can not be fully explained by density or distance to centre. While simple urban density measures have provided a starting point for understanding urban ecosystems, as Alberti (1999; 
Post-Print Version of Conway and Hackworth, 2007. Urban pattern and land cover variation 21 in the greater Toronto area. The Canadian Geographer/Le G'eographe Canadien 51(1),43-57

2005) suggests additional components of pattern- whether defined as grain, form, and

connectivity or along other dimensions- are related to ecological conditions. In the future more detailed representations of urban development pattern in particular, and human activities in general, should be incorporated into integrated urban ecological studies.

In trying to capture the interactions between land cover, specific components of urban development pattern, and socioeconomic characteristics, several additional factors that may be of equal or greater importance were not considered. First, tree by-laws, zoning regulations, and broader land use policies, as well as variation between municipal policies across the metropolitan area likely also account for some of the unexplained variation in NDVI. Additionally, programs supporting native tree plantings, community gardens, and green roofs may also play a role. Second, property-level decision making was not considered. While many of the socioeconomic variables can be thought of as proxies for individual decision-making, we are only indirectly capturing the decision-making processes of residents and other property owners. Detailed surveys and property-level assessments are needed to better understand these interactions. Third, ethno-culture factors may play a potentially important role in a diverse region like the GTA. Zmyslong and Gagnon (2000) found a strong positive spatial autocorrelation for landscaping decisions in urban Montréal, suggesting the central role of neighbour mimicry, although the cause of such mimicry was not explored. NDVI in this study was also highly spatially clustered, which resulted in the use of the spatially stratified sample. Further work should explore this pattern to determine if the autocorrelation reflects the clustering of similar ethno-cultural groups, simple neighbour mimicry, or a combination of the two.

While specific components of urban pattern were examined, NDVI was used as a simple measure of land cover and broader ecological conditions. Although correlations with other 
Post-Print Version of Conway and Hackworth, 2007. Urban pattern and land cover variation 22 in the greater Toronto area. The Canadian Geographer/Le G'eographe Canadien 51(1),43-57 ecosystem components (i.e. photosynthetic activity) are well understood, NDVI does not directly account for the type of vegetation present. In an urban area where lawn grass, planted exotics, weedy invasives, remnant vegetation from previous uses, and native species may all exist (Hough 1995), more detailed land cover measures and/or 3-D measures of below canopy conditions would contribute to a better understanding of urban ecological processes. Future research should incorporate both detailed measures of urban development and more specific measures of land cover and other ecological features to more fully address human-environmental interactions in cities. 
Post-Print Version of Conway and Hackworth, 2007. Urban pattern and land cover variation 23 in the greater Toronto area. The Canadian Geographer/Le G'eographe Canadien 51(1),43-57

\section{LITERATURE CITED}

ALBERTI, M. 2005 'The effects of urban patterns on ecosystem function’ International Regional Science Review 28(2), 168-192

ALBERTI, M. 1999 'Urban patterns and environmental performance: What do we know?’ Journal of Planning Education and Research 19, 151-163

BATTY, M, and XIE, Y. 1996 'Preliminary evidence for a theory of the fractal city’ Environment and Planning A 28 (10), 1745-1762

BLAIR, R. 1996 'Land use and avian species diversity along an urban gradient’ Ecological Applications 6, 506-519

BOTKIN, D.B. and BEVERIDGE, C.E. 1997 'Cities as environments’ Urban Ecosystems 1, 319

CHAPMAN, L.J. and PUTMAN, D.F. 1984 The Physiography of Southern Ontario. Ontario Geological Survey, Special Volume 2 (Toronto: Government of Ontario)

CMHC. 2002 ‘Residential street pattern design’ Research Highlights, Socio-economic Series, No. 75 (Ottawa: Canadian Mortgage and Housing Corporation)

DE KEERSMAECKER, M.L., FRANKHAUSER, P., and THOMAS, I. 2003 'Using fractal dimensions for characterizing intra-urban diversity: The example of Brussels’ Geographical Analysis 35 (4), 310-328

FUNG, T. and SUI, W. 2000 'Environmental quality and its changes, an analysis using NDVI' International Journal of Remote Sensing 21, 1011-1024

GEOGHEGAN, J., WAINGER, L.A., and BOCKSTAEL, N.E. 1997 'Spatial landscape indices in a hedonic framework: An ecological economics analysis using GIS’ Ecological Economics 23, $251-264$ 
Post-Print Version of Conway and Hackworth, 2007. Urban pattern and land cover variation 24 in the greater Toronto area. The Canadian Geographer/Le G'eographe Canadien 51(1),43-57

HOPE, D., GIES, C., ZHU, W., FAGAB, W.F., REDMAN, C.L., GRIMM, N.B., NELSON, A.L., MARTIN, C., and KINZIG, A. 2003 ‘Socioeconomics drive urban plant diversity” Proceedings in the National Academy of Science 100(15), 8788-8792

HOUG, M. 1995 Cities and Natural Process (New York: Routledge)

IVERSON, L.R and COOK, E.A. 2000 'Urban forest cover of the Chicago region and its relation to household density and income’ Urban Ecosystems 4, 105-124

KAPLAN, R. 2001 'The nature of the view from home: Psychological benefits' Environment and Behaviour 33 (4), 507-542

KINZIG, A.P., WARREN, P. MARTIN, C., HOPE, D., and KATTI, M. 2005 'The effects of human socioeconomic status and cultural characteristics on urban patterns of biodiversity’ Ecology and Society 10(1), 23[online]

LEMON, J. 1996 Liberal Dreams and Nature’s Limits: Great Cities of North America since 1600 (New York: Oxford University Press)

LO, C.P. and FABER, B.J. 1997 'Integration of Landsat Thematic Mapper and census data for quality of life assessment’ Remote Sensing of Environment 62, 143-157

LONGLEY, P.A. and MESEV, V. 2000 'On the measurement and generalisation of urban form' Environment and Planning A 32 (3), 473-488

LUCK, M. and WU, J. 2002 ‘A gradient analysis of urban landscape pattern: A case study from the Phoenix metropolitan region, Arizona, USA’ Landscape Ecology 17, 327-339

MARTIN, C.A., WARREN, P.S., and KINZIG, A.P. 2004 'Neighbourhood socioeconomic status is a useful predictor of perennial landscape vegetation in residential neighbourhoods and embedded small parks of Phoenix, AZ’ Landscape and Urban Planning 69, 355-368 
Post-Print Version of Conway and Hackworth, 2007. Urban pattern and land cover variation 25 in the greater Toronto area. The Canadian Geographer/Le G'eographe Canadien 51(1),43-57

MCDONNELL, M.J. and PICKETT, S.T.A. 1990 'Ecosystem structure and function along urban-rural gradients: An unexploited opportunity for ecology’ Ecology 71(4), 1232-1237

MCDONNELL, M.J., PICKETT, S.T.A., GROFFMAN, P., BOHLEN, P., POUYANT, R.V., ZIPPERER, W.C., PARMELEE, R.W., CARREIRO, M.M., MEDLEY, K. 1997 'Ecosystem processes along an urban-to-rural gradient' Urban Ecosystems 1, 21-36

MCINTYRE, N.E., KNOWLES-YÁNEZ, K., and HOPE, D. 2000 'Urban ecology as an interdisciplinary field: Differences in the use of "urban” between the social and natural sciences’ Urban Ecosystems 4, 5-25

MEDLEY, K.E., MCDONNELL, M.J., and PICKETT, S.T.A. 1995 'Forest-landscape structure along an urban-to-rural gradient’ Professional Geographer 47(2), 159-168

MILLER, R.B. and SMALL, C. 2003 ‘Cities from space: Potential applications of remote sensing in urban environmental research and policy’ Environmental Science and Policy 6(2), 129-137

NORTON, D.A. 2000 ‘Conservation biology and private land: Shifting the focus’ Conservation Biology 14(5), 1221-1223

O’CONNELL, M.A. 1996 'Managing biodiversity on private lands’ in R.C. Szaro and D.W. Johnston, eds. Biodiversity in managed landscapes: theory and practice (New York: Oxford University Press).

PICKETT, S.T.A., BURCH, Jr. W.R., DALTON, S.E., FORESMAN, T.W., GROVE, J.M. and ROWNTREE, R. 1997 'A conceptual framework for the study of human ecosystems in urban areas’ Urban Ecosystems 1, 185-199

PICKETT, S.T.A., CADENASSO, M.L., GROVE, J.M., NILON, C.H., POUYANT, R.V., ZIPPERER, W.C., and COSTANZA, R. 2001 'Urban ecological systems: Linking terrestrial 
Post-Print Version of Conway and Hackworth, 2007. Urban pattern and land cover variation 26 in the greater Toronto area. The Canadian Geographer/Le G'eographe Canadien 51(1),43-57 ecological, physical and socioeconomic components of metropolitan areas' Annual Review in Ecology and Systematics 32, 127-157

POUYANT, R.V. and MCDONNELL, M.J. 1991 'Heavy metal accumulation in forest soils along an urban to rural gradient in southern NY, USA’ Water Soil and Air Pollution 57/58, 797-807

POUYANT, R.V., MCDONNELL, M.J., PICKETT, S.T.A., GROFFMAN, P.M., and CARREIRO, M.M. 1995 ‘Carbon and Nitrogen Dynamics in Oak Stands Along an UrbanRural Gradient' in J.M. Kelley and W.W. McFee, eds. Carbon Forms and Functions in Forest Soils (Madison, WI: Soil Science Society of America)

REED, B.C., BROWN, J.F., VANDERZEE, D., LOVELAND, T.R., MERCHANT, J.W., and OHLEN, D.O. 1994 'Measuring phonological variability from satellite imagery’ Journal of Vegetation Science 5, 703-714

ROBBINS, P., POLDERMAN, A., and BIRKENHOLTZ, T. 2001 'Lawns and toxins: An ecology of the city’ Cities 18(6), 369-380

SLOCOMBE, D.S. 1993 'Implementing ecosystem-based management: Development of theory, practice and research for planning and managing a region’ BioScience 43, 612-622

SMITH, N. and O’KEEFE, P. 1980 ‘Geography, Marx, and the concept of nature’ Antipode 12, 30-39

STONE, B.J. 2004 'Paving over paradise: How land use regulations promote residential imperviousness’ Landscape and Urban Planning 69, 101-113

SUKOPP, H. 1998 ‘Urban Ecology- Scientific and Practical Aspects’ in J. Breuste, H. Feldman, and O. Uhlmann, eds. Urban Ecology (Berlin: Springer-Verlag)

SUKOPP, H. and HEJNÝ, S. 1990 Urban Ecology (The Hague: SPB Academic Publishing) 
Post-Print Version of Conway and Hackworth, 2007. Urban pattern and land cover variation 27 in the greater Toronto area. The Canadian Geographer/Le G'eographe Canadien 51(1),43-57

TUCKER, C. 1979 'Red and photographic infrared linear combination for monitoring green vegetation’ Remote Sensing of Environment 8, 127-150

WEAR, D.N., TURNER, M.G., and NAIMAN, R.J. 1998 'Land cover along an urban-rural gradient: Implications for water quality’ Ecological Applications 8(3), 619-630

WHITE, R.R. 2002 Building the Ecological City (Boca Raton: CRC Press)

WHITE, R. and G. ENGELEN. 1993 ‘Cellular-automata and fractal urban form: A cellular modeling approach to the evolution of urban land-use patterns' Environment and Planning A 25(8), 1175-1199

WICKWARE, G.M. and RUBEC, C.D.A. 1989 Ecoregions of Ontario. Ecological Land Classification Series, No 26 (Ottawa: Sustainable Development Branch, Environment Canada)

WILSON, J.S., CLAY, M., MARTIN, E., STUCKEY, D., and VEDDER-RISCH, K. 2003 'Evaluating environmental influences of zoning in urban ecosystems with remote sensing' Remote Sensing of the Environment 86, 303-321

ZHANG, L., WU, J., ZHEN, Y., and SHU, J. 2004 ‘A GIS-based gradient analysis of urban landscape pattern of Shanghai metropolitan area, China’ Landscape and Urban Planning 69, $1-16$

ZIPPERER, W.C., WU, J., POUYANT, R.V., and PICKETT, S.T.A. 2000 'The application of ecological principles to urban and urbanizing landscapes’ Ecological Applications 10(3), 685-688

ZMYSLONG, J. and GAGNON, D. 2000 'Path analysis of spatial predictors of front-yard landscapes: A random process?’ Landscape and Urban Planning 40, 295-307 
Post-Print Version of Conway and Hackworth, 2007. Urban pattern and land cover variation 28 in the greater Toronto area. The Canadian Geographer/Le G'eographe Canadien 51(1),43-57

Table 1 Urban development pattern and socioeconomic variables

\begin{tabular}{|c|c|}
\hline Variable Name & Description \\
\hline Dist_Centre & Euclidean distance to the centre of the city \\
\hline Parcel_Size & $\begin{array}{l}\text { The size of each parcel in meters squared, using Teranet’s } 2002 \\
\text { Property Tax Parcel Map Data for Halton, Peel, York, Durham, } \\
\text { and Toronto Regions and The City of Toronto’s } 2002 \text { Parcel } \\
\text { data for the City of Toronto. }\end{array}$ \\
\hline Roads_41x41 & $\begin{array}{l}\text { The density of roads within a } 1.0 \text { km neighbourhood, derived } \\
\text { from DMTI’s } 2004 \text { CanMap Route Logistics } 8.2 \text { Ontario } \\
\text { dataset }\end{array}$ \\
\hline Pop_Denisty & Population density, by dissemination area from 2001 Census \\
\hline Dwell_Age & $\begin{array}{l}\text { Dominant age of house, by dissemination area from } 2001 \\
\text { Census }\end{array}$ \\
\hline Land_Diversity & $\begin{array}{l}\text { Number of land uses present within a } 1.0 \text { km neighbourhood, } \\
\text { derived from DMTI’s } 2004 \text { CanMap Route Logistics } 8.2 \\
\text { Ontario dataset. Maximum value = } 6\end{array}$ \\
\hline Per_Owned & $\begin{array}{l}\text { Percent of dwelling units owner-occupied, by dissemination } \\
\text { area from } 2001 \text { Census }\end{array}$ \\
\hline Ind-Comm_41x41 & $\begin{array}{l}\text { Percent of land used for industrial and commercial purposes } \\
\text { within a } 1.0 \mathrm{~km} \text { neighbourhood, derived from DMTI’s } 2004 \\
\text { CanMap Route Logistics } 8.2 \text { Ontario dataset }\end{array}$ \\
\hline Green_41x41 & $\begin{array}{l}\text { Percent of land that is open or parkland within a } 1.0 \mathrm{~km} \\
\text { neighbourhood, derived from DMTI’s } 2004 \text { CanMap Route }\end{array}$ \\
\hline
\end{tabular}


Post-Print Version of Conway and Hackworth, 2007. Urban pattern and land cover variation 29 in the greater Toronto area. The Canadian Geographer/Le G'eographe Canadien 51(1),43-57

\begin{tabular}{|c|c|}
\hline & Logistics 8.2 Ontario dataset \\
\hline \multirow[t]{2}{*}{ Park_41x41 } & $\begin{array}{l}\text { Percent of parkland within a } 1.0 \text { km neighbourhood, derived } \\
\text { from DMTI’s } 2004 \text { CanMap Route Logistics } 8.2 \text { Ontario }\end{array}$ \\
\hline & dataset \\
\hline \multirow[t]{2}{*}{ Med_HH_Inc } & Median household income, by dissemination area from 2001 \\
\hline & Census \\
\hline \multirow[t]{2}{*}{ Avg_Val_Dwell } & Average value of dwelling units, by dissemination area from \\
\hline & 2001 Census \\
\hline \multirow[t]{2}{*}{ Rooms } & Average number of rooms, by dissemination area from 2001 \\
\hline & Census \\
\hline \multirow[t]{2}{*}{ Ind-Comm_7x7 } & $\begin{array}{l}\text { Percent of land used for industrial and commercial purposes } \\
\text { within a } 0.1 \mathrm{~km} \text { neighbourhood, derived from DMTI’s } 2004\end{array}$ \\
\hline & CanMap Route Logistics 8.2 Ontario dataset; proxy for view \\
\hline \multirow[t]{2}{*}{ Green_7x7 } & $\begin{array}{l}\text { Percent of land that is open or parkland within a } 0.1 \mathrm{~km} \\
\text { neighbourhood, derived from DMTI's } 2004 \text { CanMap Route }\end{array}$ \\
\hline & Logistics 8.2 Ontario dataset; proxy for view \\
\hline \multirow[t]{2}{*}{ Park_7x7 } & $\begin{array}{l}\text { Percent of parkland within a } 0.1 \text { km neighbourhood, derived } \\
\text { from DMTI’s } 2004 \text { CanMap Route Logistics } 8.2 \text { Ontario }\end{array}$ \\
\hline & dataset; proxy for view \\
\hline \multirow[t]{3}{*}{ Roads_7x7 } & Road density within a 0.1 km neighbourhood, derived from \\
\hline & DMTI’s 2004 CanMap Route Logistics 8.2 Ontario dataset; \\
\hline & proxy for view \\
\hline
\end{tabular}


Post-Print Version of Conway and Hackworth, 2007. Urban pattern and land cover variation 30 in the greater Toronto area. The Canadian Geographer/Le G'eographe Canadien 51(1),43-57

Table 2 Correlations between NDVI and independent variables for the four transects*

\begin{tabular}{|c|c|c|c|c|}
\hline \multirow[b]{2}{*}{ Variable Name } & \multicolumn{4}{|c|}{ NDVI } \\
\hline & Transect A & Transect B & Transect C & Transect D \\
\hline Dist_Centre & .322 & .455 & .631 & .448 \\
\hline Parcel_Size & .253 & .228 & .254 & .073 \\
\hline Roads_Density & -.388 & -.466 & -.598 & -.249 \\
\hline Pop_Denisty & -.312 & -.241 & -.423 & -.283 \\
\hline Dwell_Age & -.031 & .160 & -.168 & .320 \\
\hline Land_Diversity & -.293 & -.394 & -.517 & -.283 \\
\hline Per_Owned & .316 & .276 & .371 & .511 \\
\hline Ind-Comm_41x41 & -.425 & -.344 & -.426 & -.473 \\
\hline Green_41x41 & .359 & .528 & .586 & .192 \\
\hline Park_41x41 & .127 & .072 & -.088 & .182 \\
\hline Med_HH_Inc & .237 & .307 & .456 & .365 \\
\hline Avg_Val_Dwell & .144 & .351 & .366 & .376 \\
\hline Rooms & .396 & .492 & .468 & .557 \\
\hline Ind-Comm_7x7 & -.358 & -.233 & -.280 & -.363 \\
\hline Green_7x7 & .373 & .533 & .601 & .128 \\
\hline Park_7x7 & .183 & .136 & .061 & .194 \\
\hline Roads_7x7 & -.393 & -.367 & -.543 & -.178 \\
\hline
\end{tabular}

* All correlations significant at $\mathrm{p}<0.01$. 
Post-Print Version of Conway and Hackworth, 2007. Urban pattern and land cover variation 31 in the greater Toronto area. The Canadian Geographer/Le G'eographe Canadien 51(1),43-57

Table 3 Multiple regression analysis of four transects

\begin{tabular}{|c|c|c|c|c|}
\hline & $\begin{array}{c}\text { Unstandardized } \\
\text { Beta }\end{array}$ & Std. Error & $\begin{array}{c}\text { Standardized } \\
\text { Beta }\end{array}$ & $\mathrm{t}^{*}$ \\
\hline \multicolumn{5}{|c|}{ TRANSECT A } \\
\hline (Constant) & -0.057 & 0.008 & & -6.982 \\
\hline Roads_7x7 & -0.005 & 0.000 & -0.221 & -22.812 \\
\hline Dist_Centre & 0.000 & 0.000 & 0.161 & 13.604 \\
\hline Rooms & 0.017 & 0.001 & 0.159 & 15.914 \\
\hline Comm_7x7 & -0.004 & 0.000 & -0.159 & -16.644 \\
\hline Comm_41x41 & 0.000 & 0.000 & -0.136 & -13.272 \\
\hline Dwell_Age & 0.001 & 0.000 & 0.131 & 16.407 \\
\hline Park_7x7 & 0.002 & 0.000 & 0.105 & 12.095 \\
\hline Avg_Val_Dwell & 0.000 & 0.000 & 0.088 & 9.205 \\
\hline Green_7x7 & 0.000 & 0.000 & 0.065 & 6.267 \\
\hline \multicolumn{5}{|l|}{$R$-square $=0.38$} \\
\hline \multicolumn{5}{|c|}{ TRANSECT B } \\
\hline (Constant) & -0.290 & 0.008 & & -37.240 \\
\hline Dist_Centre & 0.000 & 0.000 & 0.303 & 31.645 \\
\hline Rooms & 0.041 & 0.002 & 0.279 & 21.532 \\
\hline Green_7x7 & 0.002 & 0.000 & 0.232 & 23.807 \\
\hline Avg_Val_Dwell & 0.000 & 0.000 & 0.142 & 19.625 \\
\hline Park_41x41 & 0.000 & 0.000 & 0.139 & 16.110 \\
\hline Per_Owned & -0.112 & 0.008 & -0.132 & -13.224 \\
\hline Park_7x7 & 0.003 & 0.000 & 0.131 & 15.244 \\
\hline
\end{tabular}


Post-Print Version of Conway and Hackworth, 2007. Urban pattern and land cover variation 32 in the greater Toronto area. The Canadian Geographer/Le G'eographe Canadien 51(1),43-57

$\begin{array}{llccr}\text { Parcel_Size } & 0.000 & 0.000 & -0.116 & -15.195 \\ \text { Comm_7x7 } & -0.003 & 0.000 & -0.069 & -10.851 \\ R \text {-square }=0.43 & & & \end{array}$

TRANSECT C

\begin{tabular}{|c|c|c|c|c|}
\hline (Constant) & -0.076 & 0.005 & & -13.916 \\
\hline Dist_Centre & 0.000 & 0.000 & 0.543 & 63.229 \\
\hline Park_7x7 & 0.004 & 0.000 & 0.188 & 22.935 \\
\hline Roads_7x7 & -0.004 & 0.000 & -0.180 & -21.927 \\
\hline Avg_Val_Dwell & 0.000 & 0.000 & 0.126 & 16.689 \\
\hline Comm_7x7 & -0.005 & 0.000 & -0.112 & -18.330 \\
\hline Park_41x41 & 0.000 & 0.000 & 0.080 & 9.303 \\
\hline Parcel_Size & 0.000 & 0.000 & -0.075 & -11.136 \\
\hline \multicolumn{5}{|l|}{$R$-square $=0.50$} \\
\hline \multicolumn{5}{|c|}{ TRANSECT D } \\
\hline (Constant) & -0.121 & 0.009 & & -13.366 \\
\hline Rooms & 0.025 & 0.001 & 0.286 & 25.664 \\
\hline Dist_Centre & 0.000 & 0.000 & 0.270 & 25.254 \\
\hline Park_7x7 & 0.003 & 0.000 & 0.220 & 22.600 \\
\hline Comm_41x41 & 0.000 & 0.000 & -0.182 & -17.626 \\
\hline Dwell_Age & 0.001 & 0.000 & 0.150 & 15.735 \\
\hline Roads_7x7 & -0.002 & 0.000 & -0.111 & -12.043 \\
\hline R-squar & & & & \\
\hline
\end{tabular}

* All variables significant at $\mathrm{p}<0.001$. 
Post-Print Version of Conway and Hackworth, 2007. Urban pattern and land cover variation 33 in the greater Toronto area. The Canadian Geographer/Le G'eographe Canadien 51(1),43-57

\section{FIGURE CAPTIONS}

Figure1. The location of the study area and four transects.

Figure 2. Land use in the study area.

Figure 3. The Normalized Difference Vegetation Index (NDVI) in the study area.

Figure 4. The range of Normalized Difference Vegetation Index (NDVI) values for selected land uses. 


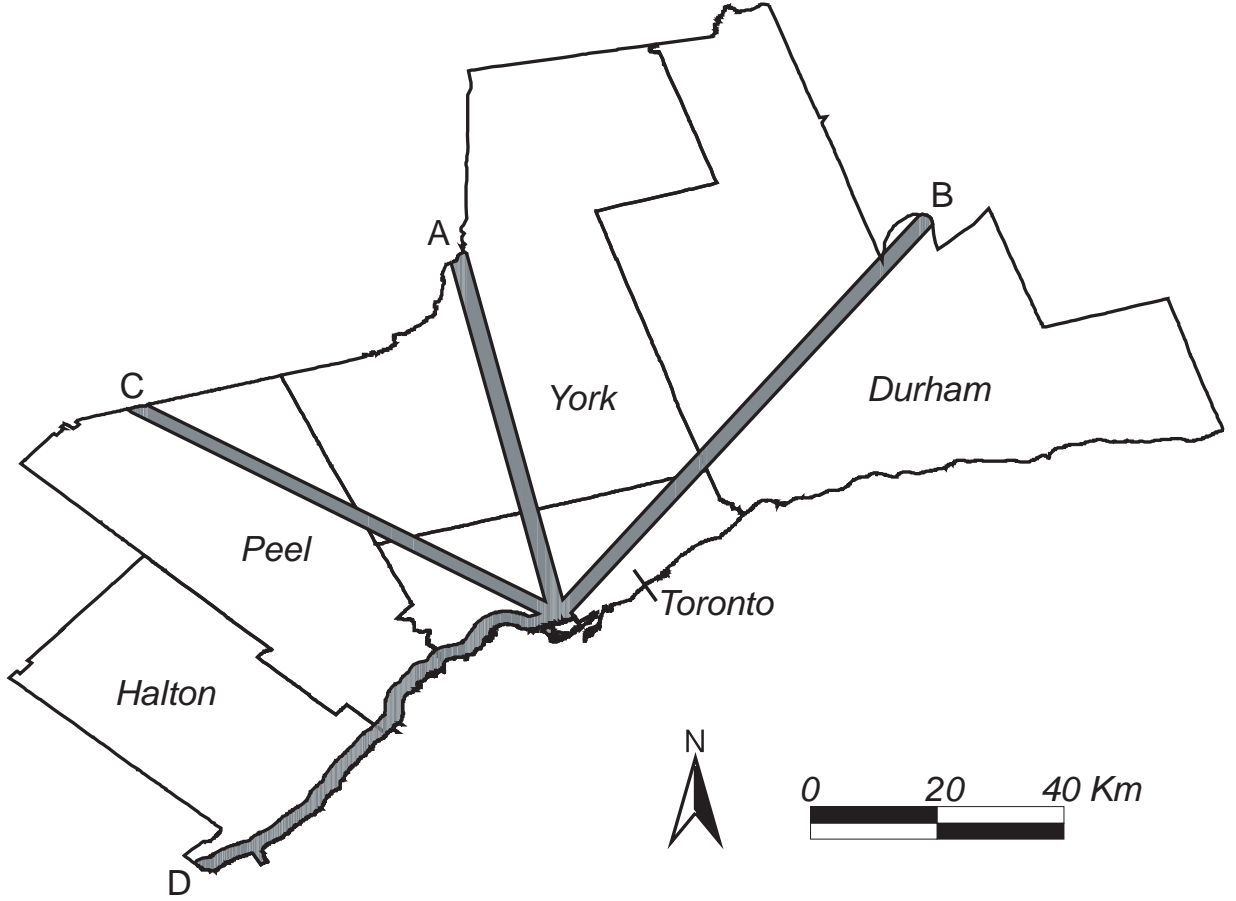




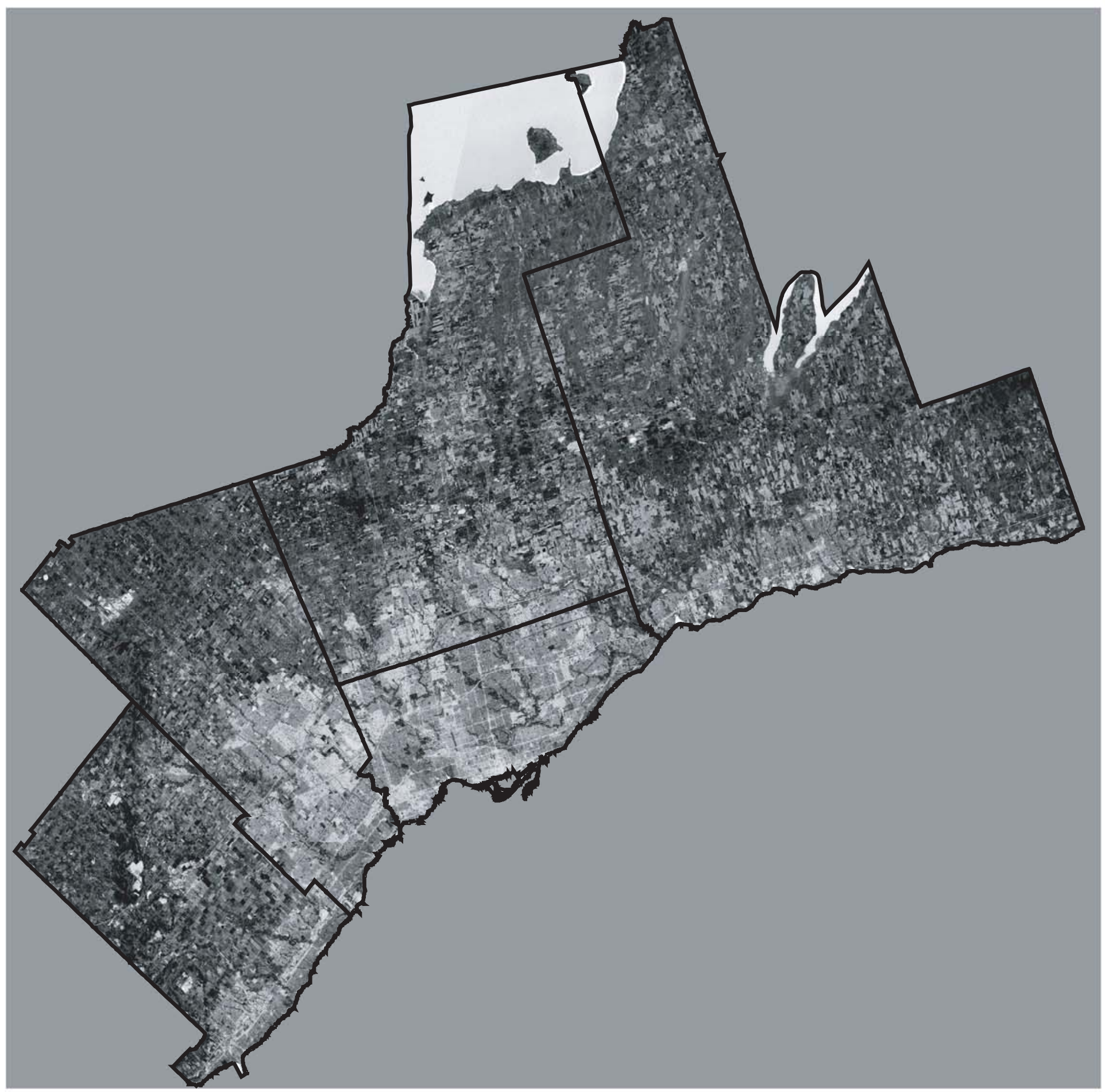




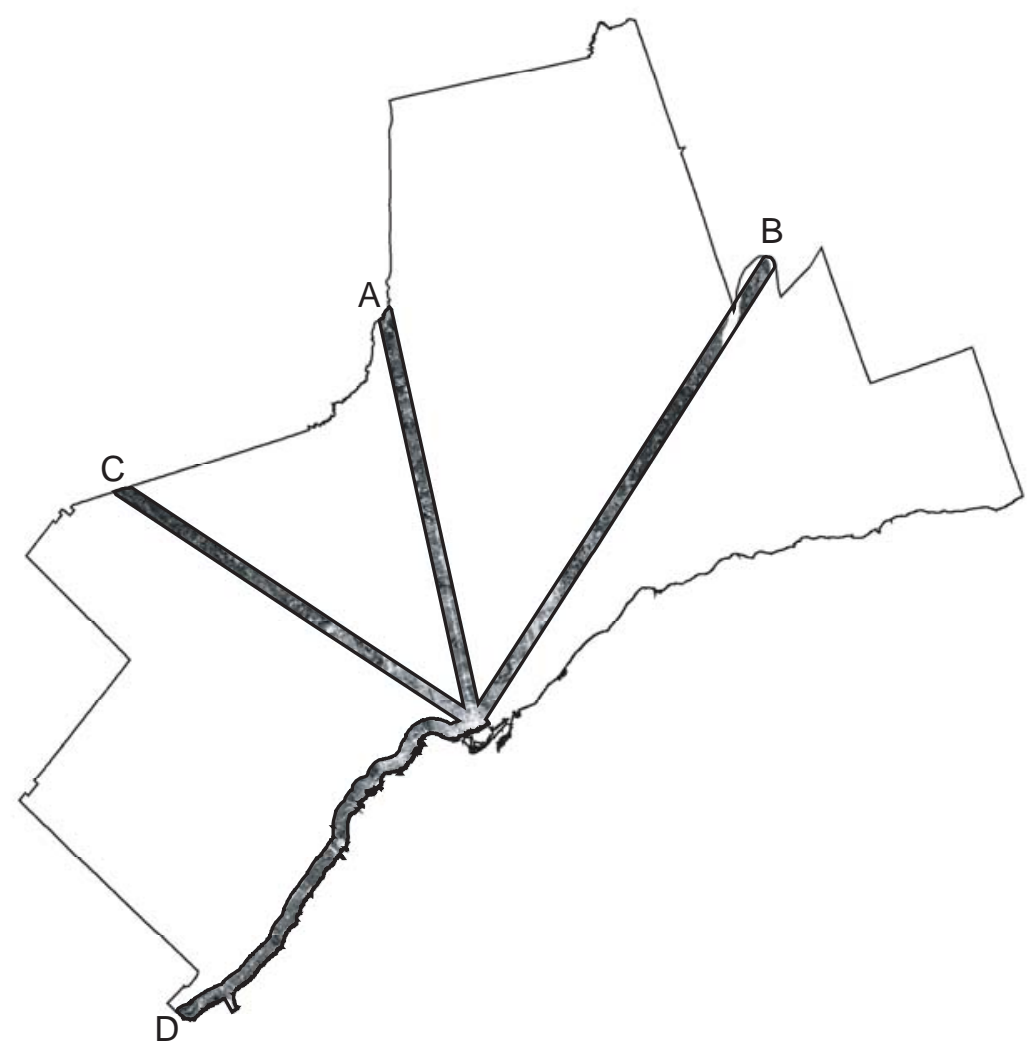




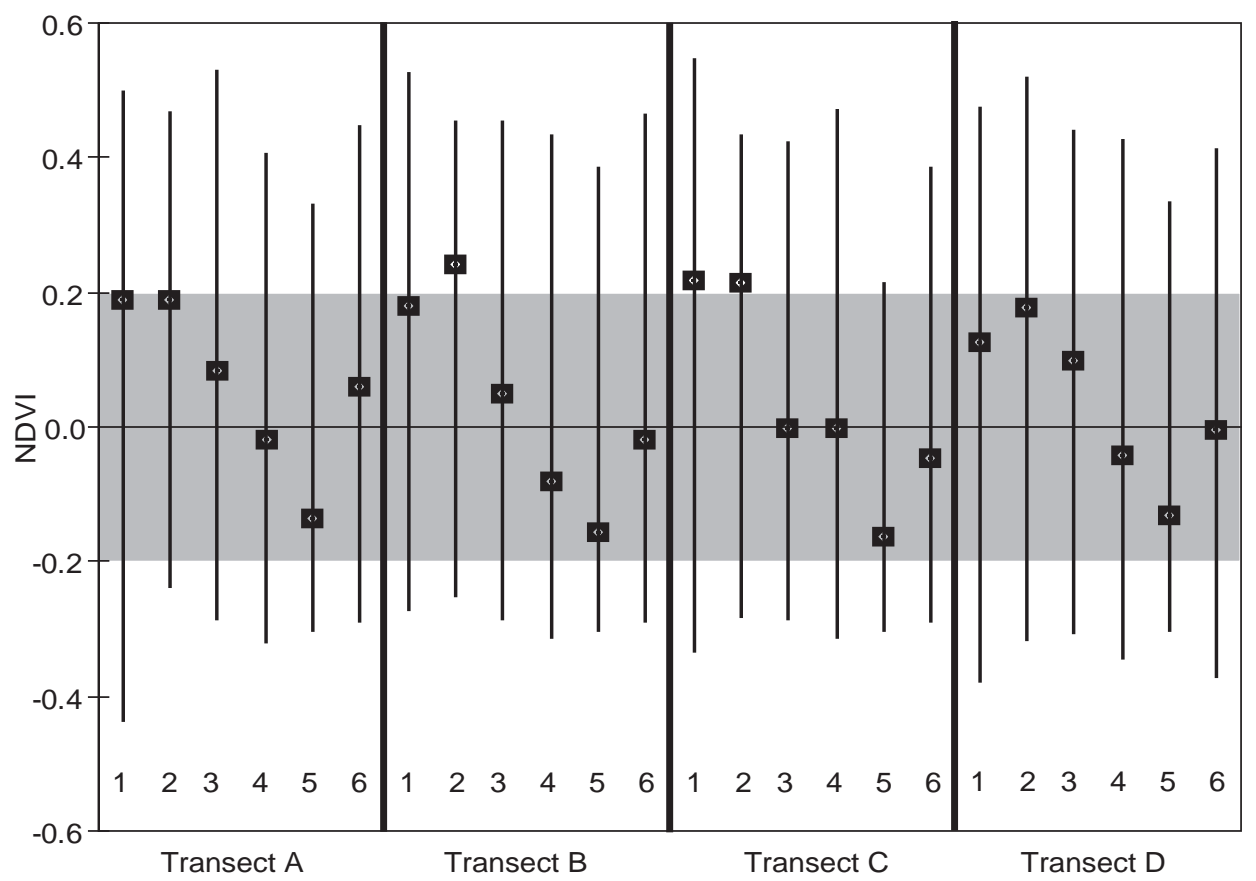

